\title{
LEGAL PROTECTION FOR CUSTOMER SEGREGATED ACCOUNT OWNER FROM LOSS DUE TO THE BANKCRUPTY OF FUTURES BROKERAGE FIRM
}

\author{
Yessy Meryantika Sari \\ Faculty of Law Universitas Islam Ogan Komering Ilir Kayuagung \\ E-mail: yessymsari@gmail.com
}

\begin{abstract}
Commodity futures trading is a business activity that is complex and involves many parties including Client Segregated Account and Brokerage Company. This business promises huge benefits but balanced with a high risk of loss. Therefore, a potential event of bankruptcy. Customer as the owner of the funds which mandated funds to the brokerage company to be managed for purposes of the transaction, should get legal protection from potential losses due to bankruptcy of futures brokerage firm. The spirit of the law in protection for customers is reflected in the preamble of legal norms futures trading as further elaborated in the general legal provisions stipulated in the Futures Trading Act.
\end{abstract}

Keywords: legal protection, customer segregated account owner, broker, bankruptcy law

\begin{abstract}
Abstrak
Perdagangan berjangka komoditi merupakan kegiatan bisnis yang kompleks dan melibatkan banyak pihak diantaranya Nasabah Pemilik Rekening Terpisah dan Perusahaan Pialang Berjangka. Bisnis ini menjanjikan keuntungan yang besar tetapi diimbangi juga dengan risiko kerugian yang tinggi. Oleh sebab itu sangat potensial terjadi kepailitan. Nasabah sebagai pemilik dana yang mengamanatkan dananya kepada perusahaan pialang untuk dikelola guna keperluan transaksi, harus mendapatkan perlindungan hukum dari potensi kerugian akibat kepailitan perusahaan pialang berjangka. Semangat hukum dalam perlindungan bagi nasabah terefleksi dalam konsideran norma hukum perdagangan berjangka yang kemudian dijabarkan dalam ketentuan hukum umum yang diatur dalam Undang-Undang Perdagangan Berjangka Komoditi.
\end{abstract}

Kata kunci : perlindungan hukum, nasabah pemilik rekening terpisah, perusahaan pialang berjangka, hukum kepailitan

\section{Introduction}

Commodity Futures Trading or often be called as the futures market or commodity market is a complex business activity that involves many parties such as a future broker. Broker is a business entity that conducts trading activities of Commodity Futures Contract based on the mandate of the Customer. In conducting its activities as mentioned above, Brokerage receives margin, namely the amount of money or securities to be placed by the Customer at the Futures Broker to ensure the implementation of the futures contract transaction which further the margin shall be stored separately from the Brokerage's company assets in the segregated account which is the brokerage accounts at De- pository Bank approved by Commodity Futures Trading Regulatory Agency (Bappebti).

In accordance with the business philosophy of futures trading which is high return high risk principle, profits that are obtained by means of this trade is very high, but the benefits are also offset by the risk of high losses. That is why it is so potential there will bankruptcy by creditors or even the debtor towards the futures brokerage firm.

Based on the theory of bankruptcy, Andi Sanjaya, ${ }^{2}$ et.al. says that:

Amser Irawan Panjaitan, 2011, Hak Nasabah Dalam Penyalahgunaan Rekening Terpisah Pada Perusahaan Pialang Berjangka Yang Dinyatakan Pailit, available at http://www.bappebti.go.id/id/edu/articles/detail/104 7.html accessed on 19 September 2012 at 10:11 wib. 
"The bankruptcy is a situation in the which companies can no longer afford or fail to meet its obligations to creditors Because The company dose not already have or lack the funds to keep the company's operations running, so the goal of the company's economic to gain profit is not Achieved ".

Bankruptcy of the futures brokerage causes the loss of the right to control, regulate and/or divert the wealth of futures brokerage firm, so that acoording to the law, the right is temporarily controlled by the curator to do a settlement of the company debt as a bankrupt futures brokerage debtor. The legal issue that arises is the legal protection for customers from losses due to customers' funds are placed in a separated account under the rule of futures brokerage firm which is stated go bankrupt.

\section{Discussion}

Legal Protection of Customer Segragated ACcount Owner from Losses Due to Future Brokerage Firm Will Go Bankrupt

Futures brokerage firm as a limited $^{3}$ liability company may be bankrupt like other legal entities in general reckon considering the openness and loopholes in Article 2 Law of Bankruptcy-Suspension of Payments (Law of PKPU) and Law of Commodity Futures Trading (Law of PBK) itself provides the possibility of bankruptcy of a futures brokerage firm that does not only give legal effect to the legal position of the company as the debtor bankrupt and the assets of the bankruptcy estate brokerage firm as (boedel bankruptcy), but also have a legal effect on the legal position of the customer hold-

2 Andi Sanjaya, Lindrianasari dan Aminah, "Banckrupty Analysis of Banking companies in Indonesia Period 20012012 (Using the Altman Z-Score Model)", International Journal on Economics and Social Sciences, Vol. 1, No. 1, January 2015, Lampung: Universitas Bandar Lampung, page 21; Compare with Hesti Budiwati, "Analisis Rasio Keuangan Camel Terhadap Prediksi Kepailitan Pada Bank Umum Swasta Nasional di Indonesia Periode 2004-2007", Jurnal WIGA, Vol. 2, No. 2, September 2011, Lumajang: STIE Widya Guna, page 53-54.

3 Compare the term of bankrauptcy in Ari Purwadi, "Penerapan Ketentuan Kepailitan Pada Bank Yang Bermasalah", Jurnal Perspektif, Vol. XVI No. 3, May, 2011, Surabaya: Faculty of Law Universitas Wijaya Kusuma, page 132 ing segregated accounts as creditors concurrent and owners of customer funds of segregated accounts that are placed on the authorization of futures brokerage firm.

In another perspective, Shalom Rista Ginting $^{4}$ explained that the bankruptcy of a company issuing the bond put bondholders at the position as unsecured creditors. Bankruptcy can give adverse impact to the creditors. Referring to the opinion if the position of customers at brokerage firms is regarded as creditors concurrent $^{5}$ then this would be detrimental to customers because customers' funds are placed in a segregrated account instead of the funds belong to the brokerage firms and customers' funds can not be categorized as a bankruptcy estate, so that customers' funds can not be used as a means of payment by the Futures Broker Company for all debts to third parties and or its creditors. Legal protection of the customer holding the segregrated account as one of the parties harmed by the future trading firm that will go bankrupt is very important. Laws should be able to provide legal certainty on the one hand and the protection of the law on the other.

In the preamble of the Law of PBK there is legal spirit to protect the rights of the parties involved in futures trading. The formulation of the preamble of the legislation is very clear to protect all parties that involved in futures trading, especially for the customer holding an account in the disservice done by futures brokerage firm for misusing funds belonging to custo-

4 Syalom Rista Ginting, "Perlindungan Hukum Terhadap Pemegang Obligasi dalam Pailitnya Suatu Perusahaan Penerbit Obligasi", Transparency: Jurnal Hukum Ekonomi, Vol. III No. 2, January 2014, Medan: Faculty of Law Universitas Sumatera Utara, page 7; See and compare with article of Pita Permatasari, "Perlindungan Hukum Pemegang Saham Minoritas Perusahaan Terbuka akibat Putusan Pailit", Salam: Jurnal filsafat dan Budaya Hukum, Vol. 1 No. 2, November 2014 Jakarta: UIN Jakarta, page 296.

5 Compare with the article of Bagus Sujatmiko \& Anita Afriana, "Perlindungan Hukum Investor Pasar Modal Akibat Kepailitan Perusahaan Ditinjau dari Hukum Kepailitan dan Hukum Perusahaan Indonesia", Padjajaran: Jurnal Ilmu Hukum, Vol. 2, No. 2, 2015, Bandung: Faculty of Law Universitas Padjadjaran, page 264; Jamin Ginting, "Kedudukan Pemegang Saham (Investor) dalam Kepailitan Perusahaan Go Public", Jurnal Law Review, Vol. IV No. 3, March 2005, Jakarta: Faculty of Law Universitas Pelita Harapan, page 2. 
mers possessing segregrated account current event of bankruptcy brokerage firms.

Legal spirit in the protection of the law against such customers should be reflected also in the provisions of general law or the articles of the legislation that regulates commodity futures trading, both in general and a specific nature so that the concept of legal protection against the customer is concrete to create legal certainty, legal expediency and legal justice for all parties.

General Law Provisions on the Legal Protection of the customer Segragated Account Owner from Losses Due to Future Brokerage Firm Going Bankrupt

The spirit of Legal protection in legal norms of futures trading in the perspective of Philip M. Hadjon theory, namely the theory of preventive and repressive legal protection, legal protection mentioned preventive aim is to prevent disputes, which lead to the precautions taken by the government in the decision-making discretion whereas repressive protection aims to resolve disputes, including its handling in the judiciary.

Preventive Legal Protection in Futures Trading Legal Norms

In Law of PBK, preventive legal protection for customers contained in Article 51 Paragraph (4) which regulates the separation of the customer's account with the brokerage firm accounts. Separation of accounts is essential to anticipate in order to avoid mixing of the company assets and customers' funds and to avoid the funds are not abused or harassed by a futures brokerage firm out of interest for the transaction. In addition, the separation of customer account aims to provide legal protection for customers in any disputes between the customer and brokerage firm, the customer funds can not be bothered by the brokerage firm, especially when the company will go bankrupt.

Provisions regarding other legal protection contained in Article 56 Paragraph (6). In this provision has been given clear boundaries that customer funds of segregrated account owner is managed by the future brokerage firm is not including the bankruptcy estate. The fund is placed segregrated account that is maintained by the future brokerage firm aims for the payment of commissions and other expenses related to futures transactions and/or for other purposes upon written order from the customer. It is stated in Article 51 paragraph (5) Law of PBK.

It means that no right for the future brokerage firm or make the customers' funds of segregrated account owner as a debt payment company which will go bankrupt to third parties, and/or creditors. In other words, it is understood that the legislation of futures trading has given legal protection preventive as prevention of law in order to prevent misuse of funds belonging to clients by the brokerage firm by requiring the brokerage firm for placing customer funds in a special account separated from wealth of brokerage firm.

This clearly reflects the legal protection for customers as anticipation for misusing customers' funds that are not appropriate with the purpose and the usage as that is contained in the common law provisions of Article 51 Paragraph (5) Law of PBK and its explanation. Furthurmore, to prevent the emergence of losses from futures brokerage firm which will go bankrupt toward the customer holding the segregrated account, which mandates fully funds managed by the brokerage firm based on the principle of trust as outlined in the trustee agreements and agreements granting special powers for certain acts.

In Government Regulation No. 9 Year 1999 concerning Implementation of the Commodity Futures Trading set of laws on legal protection for customers that is contained in Paragraph 109 a quo mention that customer funds should be separated from the company accounts, funds were placed in a special account and must be separated from one another so that brokers futures can easily see the number and manages funds of each client so that they can anticipate the occurrence of errors in the management of customers' funds that can cause the loss. 
The provisions of Article 110 letter $(p)$ a quo also explained that the law provides legal protection as an effort to anticipate losses in the form imposes limits on the behavior of futures brokerage firm that can cause harm to the customer holding segregrated accounts either because of misusing of funds or other actions that could harm customers.

\section{Repressive Legal Protection in Futures Trad- ing Legal Norms}

Repressive legal protection in this context is to ensure that the liability was carried out in a responsible manner as agreed by the parties. If a breach of the agreement, or event of default, the aggrieved party can demand fulfillment by the agreement.

In futures trading legal norms, there is a provision that gives legal protection for customers, such protection is reflected in the form of Article 73F Paragraph (1) Law of PBK. The legislation would impose sanctions if the futures brokerage firm: first, do not treat the margin of the costumers, including additional funds from customer transactions as customers' funds; second, do not store customers' funds in segregated accounts from the futures brokerage accounts at Bank approved by Bappebti; and third, withdraw customers' funds from segregated accounts, for the payment of commissions and other fees and/ or for other purposes without a written order from the customer, in connection with transactions in futures trading.

Sanctions as mentioned above are charged to the brokearage firm as a form of legal protection repressive over prevention of abuse of rights and obligations (tort) futures brokerage firm against customers' funds. The sanctions provided in a form of legal liability for the futures brokerage firm misusing funds belonging to customers placed in segregated account, both accountable civilly, by providing for damages and criminal liability for violating the legal norms/laws of commodity futures trading comodity.

Criminal liability in a form of imprisonment for minimally one (1) year and maximally 5 (five) years, while criminal liability in a form of fines minimally Rp. $1,000,000,000.00$ (one billion rupiahs) and maximally Rp.5,000,000,000. 00 (five billion rupiahs). The liability is a general sanction and limited to violations of the rights and obligations taken by brokerage firm against funds of costumer holding segregated account.

In Government Regulation No. 10 Year 1999 concerning Implementation of the Commodity Futures Trading, also arranged the repressive legal protection provided by Bappebti, in the form of administrative sanctions. Form of administrative sanction is regulated by Article 114 a quo in the form of a written warning, administrative penalty or obligation to pay certain amount of money, restrictions on business activities, suspension of business activity, business license revocation, cancellation of approval and registration certificate.

If the futures brokerage firm disobey the terms and do not separate customer accounts in segregated accounts, then based on Article 127 a quo may be charged to administrative sanctions, the obligation to pay a sum of money maximally Rp.50,000,000.00 (fifty million ru-piahs) for an individual and maximally Rp.100,000,000. 00 (one hundred million rupiahs) for another parties besides an individual, who violate the legislation of commodity futures trading.

The sanctions are very important, so that each party especially brokerage firm does not ignore the rights of customers and need to protect the rights of customers so they feel safe in doing transactions in commodity futures trading. Furthermore, the futures trading law norms also provide legal protection to customers in the form of legal regulation about the compensation fund. In Article 46 Law of PBK mentions about the existence of legal protection for the customer segregated account owner due to losses because of futures brokerage firm declared bankrupt by the court. Customer may prosecute the compensation to the Commodity Futures Exchange with given compensation fund and if the payment of compensation still remain the financial obligations to be fulfilled by the brokerage 
firm, then the liability can be prosecuted as brokerage debt. ${ }^{6}$

The obligation to pay compensation as regulated in the article above is a form of civil liability futures brokerage firm because of the actions have harm customers. Article 1131 Civil Code which states that "Any belongings of debtor, either it is moving or not moving, either it is already exist or will be exist in the future, would be a dependent for any individuals engagement." It can be understood that any action carried out by someone in the field of wealth will always carry a result of wealth, either the increasing amount of wealth (credit), and also the decreasing amount of its assets (debit). ${ }^{7}$

The provisions of Article 1132 Civil Code states that the material becomes a guarantee for all those who give them debt; sales revenue of the objects are divided according to its equilibrium, ie, according to the size of the individual receivable, unless there are legitimate reasons among creditors. It means that in article 1132 Civil Code is determined that the segregated account owner are entitled to the fulfillment of the engagement must have the fulfillment of the engagement of the assets of the incumbent (brokerage firm) in pari passu, which is they will get repayment without precedence, and pro rata, it is calculated proportionally based on the amount of each receivable compared to their accounts as a whole, to the entire assets of futures brokerage firm. Customer segregated account owner are located as unsecured creditors in bankruptcy of futures brokerage firm. So the fulfillment of obligations taken proportionally in accordance with the provisions of bankruptcy law.

6 Bambang Pratama, "Kepailitan dalam Putusan Hakim ditinjau dari Perspektif Hukum Materil dan Formil", Jurnal Disparitas Yudisial, Vol. 7 No. 2, August, 2014, Jakarta: Komisi Yudisial Republik Indonesia, page 157.

7 Agus Salim Harahap, "Tanggung Jawab Direksi dalam Kepailitan Perseroan Terbatas", Lex Jurnalica: Jurnal Hukum, Vol. 5 No. 3, August, 2008, Jakarta: Faculty of Law Universitas Esa Unggul, page 159-167; See and compare with the article of Asep Suryadi, "Tanggung Ja-wab Direksi dalam Kepailitan Perseroan Terbatas", Jur-nal Wawasan Hukum, Vol. 26 No. 1, February, 2012, Bandung: Sekolah Tinggi Hukum Bandung, page 471-485.
It is suitable with Aristotle's theory of justice $^{8}$ which stated that the law must be understood in the sense of similarity. Aristotle divided the similarities into numerical similarity that created the principle of "all people are equal before the law" and proportional similarities that created the principle of "giving everyone what they are deserved". Based on this theory, the segregated account owners have equal rights to be protected by law from losses due to bankruptcy of brokerage firm as well as creditors and debtors (brokerage firm).

Further explanation according to Aristotle, justice is divided into distributive justice and corrective justice. Distributive justice refers to the principle that everyone in the community should have the same part to the property or anything that can be shared, while the corrective justice aims to improve the situation if the application of the equality principle in distributive justice that actually caused suffering or loss of one of the parties. Corrective justice aims to restore "balance" which is disturbed by the application of the principle of equality in distributive justice. It means the purpose of justice is to recreate a fair distribution that exists to eliminate the arising imbalances. ${ }^{9}$

Referring to the theory, based on the theory of distributive justice that segregated account owners harmed by the bankruptcy of futures brokerage firm, should still get the fulfillment of obligations by the brokerage firm as well as the other creditors from the wealth contained in brokerage firm. But when the fulfillment of obligations by the bankruptcy brokerage firm to other creditors, it will cause suffering or loss for segregated account owners, then based on the theory of corrective justice, there should be efforts to other legal protection granted to the segregated account owners in order to restore the balance of parties' interests so that will be no party feels aggrieved. ${ }^{10}$

8 Bernard L. Tanya, 2010, Teori Hukum : Strategi Tertib Manusia Lintas Ruang dan Generasi, Yogyakarta: Genta Publishing, page 43-44.

9 Ibid, page 45.

10 Ardy Billi Lumowa, "Tanggung Jawab Perusahaan Yang Dinyatakan Pailit Terhadap Pihak Ketiga”, Lex Privatum, 
Law No 32 Year 1997 as a general law (lex generalis) and Law No. 37 Year 2004 as the norm of the special law (lex specialis) does not clearly identify the position of the Customer in the level of creditors, whether the prior payment or not, so that the segregated account owner can be categorized as Concurrent creditors that receive payment in pari passu and pro rata after the separatist creditor and preferred creditors (privileged) which means received payment from the rest of the division of the bankruptcy estate after separatist creditors and preferred creditors. It is very harmful to the Customer because of Customer's funds in the Segregated Account do not belong to brokerage firm, but purely belonging to the Customer which is managed by the brokerage firm and the fund can not be categorized as the bankruptcy estate which can be used to pay by the Futures Broker to pay all the debts to the third parties or creditors.

Law No 37 Year 2004 also does not specifically regulate legal effort that can be used by the Customer in the bankrupt broker and there are no rules that accommodate the interests of the Customer of bankrupt broker, so that the legal protection of Brokerage Customers remains weak despite the Broker bankruptcy has actually been regulated quite clearly in Article 51 Paragraph (6) Law No. 32 Year 1997 concerning customer funds in their Segregated Account in bankrupt broker, namely the Customer's funds in the Broker's control can not be used to fulfill the Broker obligation towards third parties or creditors.

\section{Conclusions}

The legal spirit in legal protection to customers over misusing customers' funds by bankrupt brokerage firm reflected in the preamble of legal norms futures trading which is described in the general legal provisions but not concrete. Futures Trading Act only provides general legal protection (abstract) in the form of preventive legal protection, which is separating customers' funds with the company assets in se-

Vol. I, No. 3, July 2013, Manado: Faculty of Law Universitas Sam Ratulangi, page 18-27. gregated accounts owned by Customer which is managed by the Brokerage Firm and also repressive legal protection through the private accountability, which is providing penalties and also public accountability in the form of imprisonment if the brokerage company misuses the customers' funds.

\section{References}

Budiwati, Hesti. “Analisis Rasio Keuangan Camel Terhadap Prediksi Kepailitan Pada Bank Umum Swasta Nasional di Indonesia Periode 2004-2007". Jurnal WIGA. Vol. 2 No. 2. September 2011. Lumajang: STIE Widya Guna;

Ginting, Jamin. "Kedudukan Pemegang Saham (Investor) dalam Kepailitan Perusahaan Go Public". Jurnal Law Review. Vol. IV No. 3. March 2005. Jakarta: Faculty of Law Universitas Pelita Harapan;

Ginting, Syalom Rista. "Perlindungan Hukum Terhadap Pemegang Obligasi dalam Pailitnya Suatu Perusahaan Penerbit Obligasi”. Transparency: Jurnal Hukum Ekonomi. Vol. III No. 2. January 2014. Medan: Faculty of Law Universitas Sumatera Utara;

Harahap, Agus Salim. "Tanggung Jawab Direksi dalam Kepailitan Perseroan Terbatas". Lex Jurnalica: Jurnal Hukum. Vol. 5 No.3. August. 2008. Jakarta: Faculty of Law Universitas Esa Unggul;

Lumowa, Ardy Billi. "Tanggung Jawab Perusahaan Yang Dinyatakan Pailit Terhadap Pihak Ketiga”. Lex Privatum. Vol. I No. 3. July 2013. Manado: Faculty of Law Universitas Sam Ratulangi;

Panjaitan, Amser Irawan. 2011. Hak Nasabah Dalam Penyalahgunaan Rekening Terpisah Pada Perusahaan Pialang Berjangka Yang Dinyatakan Pailit. available at http:// www.bappebti.go.id/id/edu/articles/det ail/1047.html accessed on 19 September 2012 at 10:11 wib;

Permatasari, Pita. "Perlindungan Hukum Pemegang Saham Minoritas Perusahaan Terbuka akibat Putusan Pailit”. Salam: Jurnal filsafat dan Budaya Hukum. Vol. 1 No. 2. November 2014 Jakarta: UIN Jakarta;

Pratama, Bambang. "Kepailitan dalam Putusan Hakim ditinjau dari Perspektif Hukum Materil dan Formil". Jurnal Disparitas Yudisial. Vol. 7 No. 2. August. 2014. Jakarta: Komisi Yudisial Republik Indonesia; 
Purwadi, Ari. "Penerapan Ketentuan Kepailitan Pada Bank Yang Bermasalah". Jurnal Perspektif. Vol. XVI No. 3. May. 2011. Surabaya: Faculty of Law Universitas Wijaya Kusuma;

Sanjaya, Andi. Lindrianasari dan Aminah. "Banckrupty Analysis of Banking companies in Indonesia Period 2001-2012 (Using the Altman Z-Score Model)". International Journal on Economics and Social Sciences. Vol. 1 No. 1. January 2015. Lampung: Universitas Bandar Lampung;

Sujatmiko, Bagus \& Anita Afriana. "Perlindungan Hukum Investor Pasar Modal Akibat Ke- pailitan Perusahaan Ditinjau dari Hukum Kepailitan dan Hukum Perusahaan Indonesia”. Padjajaran: Jurnal Ilmu Hukum. Vol. 2 No. 2. 2015. Bandung: Faculty of Law Universitas Padjadjaran;

Suryadi, Asep. "Tanggung Jawab Direksi dalam Kepailitan Perseroan Terbatas". Jurnal Wawasan Hukum. Vol. 26 No. 1. February. 2012. Bandung: Sekolah Tinggi Hukum Bandung;

Tanya, Bernard L. 2010. Teori Hukum : Strategi Tertib Manusia Lintas Ruang dan Generasi. Yogyakarta: Genta Publishing. 